\title{
"Literally, there were only a few steps between the cold and warmth, and between darkness and light." The Image of the City in Smutna Wenecja by Wacław Kubacki
}

\section{S U M M A RY}

The article discusses the image of the city presented in the novel Smutna Wenecja by Wacław Kubacki, an outstanding literary historian, and how the writer's interests and experiences influenced the topic and the character of the work (he utilised his journals). The city depicted by Kubacki seems to possess a dichotomous nature. The Venetian garden of the arts and the mecca of academics was contrasted with the Venice of poor and foul recesses. The author contrasted the Venice of tourists' "unbridled excess" with the reality of the life of Venice's proletariat. The article indicates the linguistic and compositional means which the writer used to reflect that duality, beauty, and ugliness. The article also indicates the dominant features of the novel, i.e. intellectualism and sensoriness.

\section{Keywords}

20th century novel, city in literature, Wacław Kubacki, Venice

In 1967, Wacław Kubacki's Smutna Wenecja was released. Its author was a professor at the Jagiellonian University and an outstanding literary historian specialising in Romantic literature. He wrote seminal studies of the 
output of Adam Mickiewicz ${ }^{1}$, first and foremost, but also those of Feliks Bernatowicz ${ }^{2}$, Władysław Syrokomla, and Juliusz Słowacki ${ }^{3}$. He also wrote about the literature of the Enlightenment ${ }^{4}$ and 20th-century literature (e.g. about Stanisław Brzozowski, Stanisław Przybyszewski, and Witkacy). He was also interested in world literature (e.g. in the works by Alexander Pushkin, Knut Hamsun, Marcel Proust, and Voltaire $)^{5}$. The extensive scope of his interests was not limited to only strictly academic works. Kubacki was also a literary and theatre critic, ${ }^{6}$ and a leader of the Polish Writers' Union. In parallel to his activities as a literary historian and critic, creative work as a writer, playwright, and poet unfolded there. Only a year after the release of his first academic work, he published a work of literature, i.e. a play entitled Krzyk jarzębiny (1948), ${ }^{7}$ where the protagonist was Ludwik Spitznagel, a Romantic poet and Orientalist. In fact, Kubacki's entire literary output was strongly inspired by his academic interests. Prior to the release of Smutna Wenecja in 1967, he had already published five plays ${ }^{8}$ and a collection of literary miniatures. ${ }^{9}$ Since the release of Smutna Wenecja, Kubacki focussed on his literary career as - apart from a study of Sonety krymskie ${ }^{10}$ - he published one play (Tragedia Achillesa. (W swobodnej formie antycznej) $\left.{ }^{11}\right)$, three novels (Koncert na orkiestre, ${ }^{12}$ Sen nocy letniej, ${ }^{13}$ Temat $z$ wariacjami ${ }^{14}$ ), a collection

${ }^{1}$ Wacław Kubacki, Pierwiosnki polskiego romantyzmu (Krakow: Wydawnictwo M. Kot, 1949); Wacław Kubacki, Tyrteizm Adama Mickiewicza (Warsaw: [s.n.], 1949); Wacław Kubacki, Palmira i Babilon (Wrocław: Wydawnictwo Zakładu Narodowego im. Ossolińskich, 1951); Wacław Kubacki, Arcydramat Mickiewicza: studia nad III częścia „Dziadów" (Krakow: Wydawnictwo M. Kot, 1951); Wacław Kubacki, Żeglarz i pielgrzym (Warsaw: Czytelnik, 1954); Wacław Kubacki, Adam Mickiewicz: człowiek i dzieło (Krakow: PWN, 1966). Kubacki was also a member of the editorial board of the National Edition of Adam Mickiewicz' Dzieła.

${ }^{2}$ Wacław Kubacki, Twórczość Feliksa Bernatowicza (Wrocław: Wydawnictwo Zakładu Narodowego im. Ossolińskich, 1964).

${ }^{3}$ Wacław Kubacki, Poezja i proza. Studia historycznoliterackie 1934-1964 (Krakow: Wydawnictwo Literackie, 1966). 1951).

${ }^{4}$ Wacław Kubacki, "Monachomachia” przed sądem potomności (Warsaw: Książka i Wiedza,

${ }^{5}$ Wacław Kubacki, Krytyk i twórca (Łódź: Wydawnictwo Władysława Bąka, 1948); Wacław Kubacki, Lata terminowania. Szkice literackie 1932-1962 (Krakow: Wydawnictwo Literackie, 1963).

${ }^{6}$ Wacław Kubacki, Na scenie (Warsaw: Wydawnictwa Artystyczne i Filmowe, 1962).

7 Wacław Kubacki, Krzyk jarzębiny: opowieść dramatyczna w trzech aktach (Warsaw: Państwowy Instytut Wydawniczy, 1949).

${ }^{8}$ Wacław Kubacki, "Historia biblijna," Twórczość, issue 12, (1949): 84-99; Wacław Kubacki, "Paw i dziewczyna. Balet w 1. akcie," Zeszyty Wrocławskie, issue 3-4, (1949): 50-51 (an outline of libretto; Tadeusz Szeligowski's ballet staged by the Opera in Wrocław in 1949); Wacław Kubacki, Jakobińskie gniazdo. Sztuka z insurekcji warszawskiej w 6 obrazach (Warsaw: Czytelnik, 1955); Wacław Kubacki, Rzymska wiosna. Sztuka w 3 aktach (Warsaw: Czytelnik, 1955); Wacław Kubacki, “Amiel (Fantazja biblijna w 4 aktach),” Dialog, issue 4, (1957): 5-31.

${ }^{9}$ Wacław Kubacki, Kartki na wietrze (Bydgoszcz: Arkona, 1950); next edition, extended Warsaw: Czytelnik, 1969.

${ }^{10}$ Wacław Kubacki, Z Mickiewiczem na Krymie (Warsaw: Państwowy Instytut Wydawniczy, 1977).

${ }^{11}$ Wacław Kubacki, "Tragedia Achillesa. (W swobodnej formie antycznej)," Dialog, issue 5, (1970): 7-29. All of Kubacki's plays were published in: Wacław Kubacki, Tragedia Achillesa oraz inne próby dramatyczne (Poznań: Wydawnictwo Poznańskie, 1972).

${ }^{12}$ Wacław Kubacki, Koncert na orkiestre (Warsaw: Czytelnik, 1970).

${ }^{13}$ Wacław Kubacki, Sen nocy letniej (Poznań: Wydawnictwo Poznańskie, 1974).

${ }^{14}$ Wacław Kubacki, Temat z wariacjami (Warsaw: Państwowy Instytut Wydawniczy, 1982). 
of travel sketches (Malwy na Kaukazie ${ }^{15}$ ), a collection of poems (Człowiek $i$ świat $\left.^{16}\right)$, and three volumes of journals covering the period 1944-1968. ${ }^{17}$

Among all his works of literature, the greatest success, measured with the number of editions and translations, was achieved by Smutna Wenecja. Its second edition was released only a year later, i.e. in 1968, and the third in 1971. It was his only novel which was reprinted and it was translated into seven languages: Bulgarian, Lithuanian, German, Russian, Romanian, Slovak, and Hungarian. ${ }^{18}$ Kubacki's literary works were so strongly associated with the author's experiences and cultural interests that some critics treated Tadeusz, the protagonist, almost as the author's alter ego. It is difficult to avoid such associations as there are so many parallels between the protagonist and the author, which apply to their professional, intellectual, and biographical profiles.

Tadeusz was an assistant professor at the University of Warsaw on an academic trip to Italy. In Venice's St. Mark's Library, he studied source materials for a book he was preparing on the history of the empire of the Langobards (Kubacki wrote his doctorate about the Middle Ages). It was not his first trip; he had completed a similar one on the eve of the Second World War (similarly to Kubacki). After the calamities of the war, in the new political situation, a visit in Venice was also a chance to reflect on the civilisation, persistence, the extinctions which happened in humankind's history, and on the place and role of culture in that sinusoid of catastrophes (and on the lifting of oneself from them).

Considering Kubacki's biography and the records in his journals, those parallels between the protagonist and the author become striking. Also, the "rhythm" and the nature of the records in the journals are quite analogous with the language and the content of the novel. The protagonist's love affair in Venice is a new fictional plot, but even in that case one cannot state anything for certain, apart from the fact that the journal does not mention anything like that. Yet it seems that the love story could be of secondary importance for the main topic of the novel. ${ }^{19}$ It is banal, unconvincing, and considerably less engaging that the "Venetian" observations and reflections of the narrator or the protagonist.

In the novel, Venice became a symbolic city, a trademark city where the history, structure, architecture, and works of art inspire one to reflections in philosophy of history, theosophy, anthropology, and culture. Yet it also presented another face: that of a regular city, one of many, with its dirty and musty recesses, proletariat's poverty, and the sounds, smells and tastes of

\footnotetext{
${ }^{15}$ Wacław Kubacki, Malwy na Kaukazie (Warsaw: Czytelnik, 1969).

${ }^{16}$ Wacław Kubacki, Człowiek i świat (Warsaw: Krajowa Agencja Wydawnicza, 1988).

17 Wacław Kubacki, Dziennik (1944-1958) (Warsaw: Czytelnik, 1971); Wacław Kubacki, Dziennik 1959-1965 (Warsaw: Państwowy Instytut Wydawniczy, 1974); Wacław Kubacki, Dziennik (1966-1968) (Warsaw: Państwowy Instytut Wydawniczy, 1990).

${ }^{18}$ More on the editions, vide A. Szałagan, "Kubacki Wacław," in Wspótcześni polscy pisarze i badacze literatury. Stownik bibliograficzny, vol. 4, edited by a team led by J. Czachowska and A. Szałagan (Warsaw: Wydawnictwa Szkolne i Pedagogiczne, 1996), 427 (§ 22). Only one more work, i.e. Koncert na orkiestrę, was translated (into Czech; 1972).

${ }^{19}$ In a review of Smutna Wenecja, Janusz Rohoziński even argued that "the very narrative pattern gives the impression that the writer considered it as secondary." See: Janusz Rohoziński, “Wacław Kubacki,” Tygodnik Kulturalny, issue 30, (1968): 5.
} 
local everydayness. That encounter, or rather the encounter of those two worlds, is that which is most enchanting and intriguing in the novel.

Nineteen years prior to the release of the novel, Kubacki's notes in Dziennik, which he recorded in Venice on 1 May 1948, featured the first indications of his concept of a work associated with the city. In March of that year, Kubacki departed for Italy to deliver lectures. Since the University of Poznan offered him an unpaid leave, he received a subsidy from the Ministry of Culture and Art to support his family. Equipped by the state with a tailor-made evening suit and "a small allowance to purchase three shirts, pyjamas, and black shoes," ${ }^{20}$ on 29 March he departed for Italy. His first, and the longest, stop was Rome (31 March-25 April), where he returned twice during the journey (17-22 May; 8 June). Next, he visited Milan (29 April), Venice (1-4 May), Padua (4-5 May), Florence (6-7 May), Cagliari (10-12 May), Bologna (5 May), Rome (17-22 May), Capri (29-30 May), Naples (31 May), Catania (3 June), Messina (4 June), and Taormina (5-7 June).

Due to an election campaign in Italy during which it was prohibited to hold any lectures, almost the entire first month of Kubacki's journey was a period filled with library surveys, trips, and academic meetings and social gatherings. The first lecture was held in Milan on 28 April and it applied to Mickiewicz's associations with Italy. On 1 May, Kubacki arrived in Venice. In his journal, he compared his recollections of his pre-war visit in the city with the current situation:

I stood in the evening in front of the station on the Grand Canal. On the opposite side, there was the Germania della Gara Hotel. I stayed in it in late June 1939, as I was returning to Poland from Paris via Marseilles, Nice, Milan, Venice, and Vienna. Currently unavailable for me, though it progressed considerably in its life's career. During the war I feared for the fate of this beloved city. It survived unscratched from the calamity. It has become even more colourful, lively and richer. Yet it is doomed for hopeless fortune in sea loam. Suddenly, the windows in my former hotel room lit up. Their light was reflected by the dark water of the canal. They seemed like swords thrust into the heart of Our Lady of Sorrows. The lagoon's waters pierced with the swords of pain - a harbinger of suffering and extermination.

- I have to write a novel about the city some time.

That concept/image is the core of a novel I do not know yet. ${ }^{21}$

That concept-image which was supposed to constitute the core of the planned work did actually include several plots which Kubacki later used in his novel: the pre-war vs. post-war Venice, metaphors capitalising on religious concepts for describing clearly non-religious phenomena, and, finally, the recurring reflections of the kind of history of philosophy on extinctions of civilisations.

\footnotetext{
${ }^{20}$ Kubacki, Dziennik (1944-1958), 122. [Unless indicated otherwise, quotations in English were translated from Polish]

${ }^{21}$ Ibid., 129.
} 
Kubacki's pre-WWII visit in Italy was for him one of the stops in his European travels (Switzerland, Italy, France, Germany), which he completed after acquiring his doctorate degree at the Jagiellonian University based on his dissertation Mediaeval Franciscan legends (NB, the Middle Ages is a major topic in the novel). He travelled as a correspondent and a collaborator of the Wiadomości Literackie journal. His post-WWII journal includes one more recollection of his pre-WWII visit in Venice. It was triggered by an encounter with Fr. Bernardino Rizzi. He came to Kubacki's Venice lecture at Instituto Universitario di Economia e Commercio. Rizzi was a composer and a conductor. Before the Second World War, he lived in Poland, where he created and managed the Krakow-based Cecilian Choir. Kubacki recalled having written a libretto to the oratorio Chrystus i Samarytanka for him at that time. It was his first, as he called it, "dramatic attempt." ${ }^{22}$ He recorded in detail that after the lecture, a dinner was held at the Quadri restaurant in St. Mark's Square, during which omelette norvégienne with ice-cream was served. I quoted those two pieces of information from the journal, one musical and one food-related intentionally. Music and food constitute two major topics in Smutna Wenecja.

Yet he abandoned the 1948 idea for a novel, or it marinated long. The next remark about the fact of working on it appeared nine years later. The 11 July 1957 entry, from another visit in Venice, includes the following piece of information: "I decided to return to my idea from 1948. I shall write a novel about Venice. I already have the title: Smutna Wenecja."23 And, indeed, his work on it began. Two days later he wrote:

Every day, sketches for the novel. The material is expanding as I write. I'm working from dawn till dusk. (...) I am taking notes on the canals, by the tables of cheap inns, on the steps of churches and palaces. I develop more extensive sections on the lawn opposite Albergo Santa Chiara, if I can find a bench that is not occupied. ${ }^{24}$

That visit in Italy was particularly fruitful for the novel. A two-day visit in Ravenna recorded in the journal was later reflected in the novel - the protagonist's visit in the city constitutes a considerable section ${ }^{25}$. Dziennik also indicates the inspiration for the rather exotically sounding name of the protagonist's lover. On 22 August, he recorded: “Tadeusz and Zanze - those are the names that I gave today to the characters of my novel." ${ }^{26}$ He wrote that he first encountered the name Zanze in the prison memoir of Silvio Pellico, an Italian Romantic writer. ${ }^{27} \mathrm{He}$ was reminded of that as he was having a meal in a small Venetian restaurant Zanze's. Apparently, the name belonged to

${ }^{22}$ Ibid., 129-130.

${ }^{23}$ Ibid., 382.

${ }^{24}$ Ibid.

${ }^{25}$ Wacław Kubacki, Smutna Wenecja (Warsaw: Czytelnik, 1967), 83-112.

${ }^{26}$ Kubacki, Dziennik (1944-1958), 389.

${ }^{27}$ Silvio Pellico (1789-1854), a writer, poet, and a playwright. In Poland, he was known as the author of Le mie prigioni. Those were his notes on his time spent in prison, where he was sent for participating in a secret revolutionary society of the Carbonari, which played a major role in the process of the unification of Italy. The work was translated into Polish as early as in 
the owner's wife, and when inquired by Kubacki about its origin, the owner explained that it was a Venetian diminutive of Angela. Kubacki did mention that Bernardino Rizzi tried to convince him that it was rather a diminutive from Giovanna. He did not settle the dispute; he only stated concisely: "The heroin is called Zanze and that's it"28.

Less than a month after returning to Italy, on 20 September 1957, he wrote that he unpacked a "pack of notes" from his Italian trip, read, organised, and supplemented them. He must have already been writing it because he added: "Most importantly, I cannot get distracted from my work when university classes start. There is nothing worse than derailing your pen which had already gained momentum." ${ }^{29}$ Apparently, work was not progressing as quickly as he assumed it would. The following remarks about working on it can only be found five years later, when once again during an Italian trip, to Orvieto this time, he wrote: "I stopped for a day. The only goal: the cathedral and Luca Signorelli. Yet what proved more productive for my writing were the surrounding landscapes, and the steep and winding narrow streets (...) I wrote a few pages which I shall include in Smutna Wenecja." ${ }^{\prime 30}$

That remark is extremely significant for the discussion of the structure of the novel. Its reviewers have offered various approaches (though rarely comprehensively motivated) to describing it. Julian Przyboś referred to it as an "essay about culture and history." 31 The essayistic nature of the work was also emphasised by Włodzimierz Maciąg. ${ }^{32}$ Janusz Rohoziński saw the inspiration for the proposed type of narration in Romantic narrative poems. ${ }^{33}$ Finally, Stanisław Zieliński considered it a "fictionalised lecture." ${ }^{34}$ An essay, a digressive narrative poem, or a fictionalised lecture - each of those suggestions could be justified. It shares its literary/ academic nature with the essay as well as its digressive course full of loose associations; also its reflective nature, a certain degree of freedom in combining various plots, and its fictional nature, which if ever included in an essay, plays a secondary role. ${ }^{35}$ The motif of the protagonist's journey combined with a story of an affair, plus a rudimentary and episodic fictional structure are elements which approximate it to a narrative poem. Finally, the fact of defining Smutna Wenecja as a fictionalised lecture emphasises the intellectual nature of the novel, in which the fortunes of the characters are secondary to the primary intention of the narrator who is "erudite/ aesthete and an inhabitant of an ivory tower." 36

1837 (Silvio Pellico, Moje więzienia. Pamiętniki z przypisami Piotra Maroncellego, trans. F. Tustanowski, vol. 1-2, Vilnius: Nakład wydawcy, Drukarnia B. Neumana, 1837).

${ }^{28}$ Kubacki, Dziennik (1944-1958), 390.

${ }^{29}$ Ibid.

${ }^{30}$ Kubacki, Dziennik 1959-1965, 269.

31 As quoted in Marcin Czerwiński, “Kubackiego obrachunki klerkowskie," Nowe Książki, issue 15, (1968): 1032.

${ }^{32}$ Włodzimierz Maciąg, "Eseistyka i powieść," Twórczość, issue 11, (1967): 110-113.

${ }^{33}$ Rohoziński, Wacław Kubacki, 5.

${ }^{34}$ Stanisław Zieliński, "Miłość z dobrym apetytem," in: Wycieczki balonem. No 4 (Warsaw: Państwowy Instytut Wydawniczy, 1971), 144.

${ }^{35}$ Krzysztof Dybciak, “Inwazja eseju," Pamiętnik Literacki, issue 4, (1977): 118.

${ }^{36}$ Czerwiński, Kubackiego obrachunki klerkowskie, 1032. 
A small remark in Kubacki's Dziennik: "I wrote a few pages which I shall include in Smutna Wenecja" was a confirmation of that which can be seen in the novel's structure, i.e. complete freedom of including digressions, which function somewhat in tandem with the story line. When reading it, one does have the impression that the author devising the fortunes of the characters was looking for chances and locations for including those conventional "a few pages," i.e. a side plot or a loosely related association, to the narrative. The eventual proportions trigger a question about the predominant nature of the novel. It seems that, just like in a digressive narrative poem, digressions are of primary importance while the story is secondary. A good example of such an inclusion is the story of the protagonist's visit in Ravenna. As I have mentioned, Kubacki wrote in his Dziennik that he escaped from Venice to spend a few days in Ravenna. He was enchanted by the city. He wrote: "I walk around as if intoxicated. I cannot believe my eyes that anything like this could have been created in the 5th, 6th and 7th century $\mathrm{AD} .^{\prime \prime 7}$ In the novel, the reason behind the protagonist's departure from Venice to Ravenna seems to have a deus ex machina character: "A few days later he gets a call from Zanze. She did everything in her power to convince Tadeusz to leave Venice for some time. She promised she would explain everything in a letter." 38 Tadeusz, obligingly, did as she asked - he departed for Ravenna. Their relationship did not make his submitting to his lover's persuasion very convincing. Yet the protagonist's "forced" visit to Ravenna offered Kubacki a chance to develop a 28-page-long section in which he expressed his fascination with the city (the locations and historical sites which he had described in his Dziennik can also be found in the novel). Yet the subject of the discussion is, in this case, Venice itself and its somewhat split image emerging from Kubacki's novel.

\section{The Venice of squares and churches - the Venice of recesses}

The Venice depicted by Kubacki has two different yet complementary faces. The first one is a garden of culture, a paradise city for a humanist, an erudite person, a lover of art, and bibliophile. The city's history, architecture, historical sites, and works of art become an endless source of inspiration triggering intellectual reflections on various issues. As an example, please consider the recurring motif of the deluge. It first appeared when Tadeusz viewed St. Mark's Column. He confronted his reflections from his pre-WWII visit and the concerns he had had then associated with the impending war with the time after the world catastrophe. The comparisons were facilitated by notes Tadeusz made in his journal, which the author once again included in the main story.

The mosaics at St. Mark's Basilica presenting the biblical deluge were mainly a starting point for an erudite discussion of the way in which the notion of "water" was presented in various languages. That was triggered by the shape of the mosaic waves, "the wavy lines." Therefore, the author

\footnotetext{
${ }^{37}$ Kubacki, Dziennik (1944-1958), 383.

${ }^{38}$ Kubacki, Smutna Wenecja, 83.
} 
offered his readers a mini-lecture on shared human experience expressed in sign and sound-based reflections of the phenomenon first in pictographic writing systems (Egyptian, Sinaian, and Sinaian-Semite), and later in Hebrew, in Indo-European languages, Sanskrit, classical languages (Greek and Latin), and modern languages. To that, he added the similarity to Henri Matisse's maritime cut-outs, which he included with the artist's commentary in French. Yet that section also includes a reflection based on the philosophy of history. The biblical deluge offered the protagonist a sense of a "new deluge." His study of the history of Langobards, which he pursued before the war, was a starting point "against the barbarity that is knocking of the door of our era" ${ }^{\prime 39}$. He visited Post-WWII Venice to complete his work; having emerged from the war unscathed helped him realise that the calamities of war reached deeper, and it was not only limited to causing material ruin. Noah became the metonymy of the survivors. Yet the fact of surviving did not solely entail happiness and joy; it mainly meant bitterness and the harsh realisation of its price:

Other people, and animals, reptiles, birds, and butterflies died so that Noah could live. His ship ripped through shoals of children's corpses. It rubbed on the bellies of recently handsome women (...) It cut the bosoms and arms of once comely daughters of Cain. The hair of charming drowned women stuck as some ghastly seaweed to the resin-covered sides of the ship. ${ }^{40}$

In that massacre of the innocents, Tadeusz saw himself as a chance survivor, who without any apparent reason, by pure blind luck managed to avoid a similar fate. "The staleness of the God's chosen one,"41 as that was how Noah in the mosaic seemed to him, evoked in him not so much admiration as irritation. He watched him "from the perspective of one of those who were condemned to drown but who survived by accident." ${ }^{\prime 2}$ That declaration resembles the declaration by another survivor, from Różewicz' poem: "Mam dwadzieścia cztery lata / Ocalałem / prowadzony na rzeź" ${ }^{\prime \prime 3}$ [I am twenty-four / I survived / having been led to a massacre]. The survivor's perspective shall remain changed for ever. The poet continued:

Szukałem nauczyciela i mistrza niech przywróci mi wzrok słuch i mowę niech jeszcze raz nazwie rzeczy i pojęcia niech oddzieli światło od ciemności. ${ }^{44}$

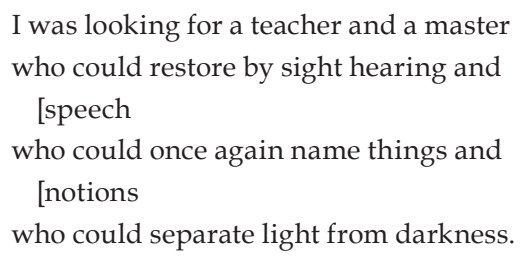

\footnotetext{
${ }^{39}$ Ibid., 17.

${ }^{40}$ Ibid., 23.

${ }^{41}$ Ibid.

42 Ibid.
}

43 Tadeusz Różewicz, Niepokój. Wiersze z lat 1945-1946 (Wrocław: Wydawnictwo Zakładu Narodowego im. Ossolińskich, 1980), 15.

${ }^{44}$ Ibid., 15-16. 
Kubacki's protagonist seems disillusioned. He regained his sight, hearing, and speech, thus he could see, hear and name that which he previously only sensed would happen:

Survivor by accident, a representative of humankind stood by the lagoon and watched as the bows of gondolas rhythmically rose and fell, glistening in the sun with their metal fittings. (...) At that moment, Tadeusz heard with his internal ear a string break in him in a short muffled crack, a string which he had many years before tried to tune here to the rocking boats, a tune suggested to his youthful imagination by poets and travellers. The bows of Venetian gondolas absolutely did not resemble either the violin or the lute. They were a combination of a sawtooth and a saw. Some oriental cleaver. A styled Norse axe. A transformed kind of a halberd. A gondola is just a tamed through the centuries descendant of old pirate barges, which iron-clad bows butted, jabbed, cut, slashed, dug, tore, and ripped..$^{45}$

This fragment also includes typical features of the novel - music-based metaphors, and an inclination for accumulating certain words and related structures. Just as in the above quotation in which violin/gondolas and lute/ gondolas transform in Tadeusz's imagination into a multitude of tools for fighting and violence, and their struggles with the resistance of water also take on a military guise as they butt, cut, slash, dig, tear and rip preventing the protagonist from "tuning" his imagination to the pre-war tone, i.e. pre-disaster associations.

Biblical tradition and metaphors clash in the novel with their pre-Christian, non-Christian and anti-Christian counterparts. That was the case when the protagonist searched for a spiritual alter ego, which he could not find in Noah. The latter keeps re-emerging as a survivor figure, yet always in a way in which one can see at least some distance towards the biblical patriarch. When the protagonist visited his friend and historian living in Italy to thank him for his help in acquiring a visa, he noticed with some surprise that the world in which his friend operated seemed to be an enclave which emerged from the disaster of the Second World War unscathed. That persistence, so surprising for the protagonist, was triggered by his recollection of his pre-war visit:

The professor made a gesture which Christ used to calm the sea in some old Italian painting. Then he rang. A pretty girl with copper hair entered. Her eyes were oblong and glistened moistly. A white apron on a black dress and skittish caul on her head. She brought a platter full of peaches. She set up a beautiful Sienna wine set on the table. From a pitcher with a small white and green ornament, golden wine was dripping into cups with white and green patterns. ${ }^{46}$

\footnotetext{
${ }^{45}$ Kubacki, Smutna Wenecja, 24.

${ }^{46}$ Ibid., 40.
} 
The recollection of the meeting from the past and the transition to the current day were, for Tadeusz, a kind of a dejà vu. Two pages further feature the following record of the post-war visit:

The professor raised his hand with his hieratic gesture, with which he seemed to be calming tempestuousness of the sea. And then he rang. A pretty girl with copper hair stood in the door. She had, like the one from before the war, oblong eyes with a moist glisten. White apron on a black dress and skittish caul on her head. Tadeusz' heart leapt. Peaches! That same beautiful Sienna with white and green patterns! ${ }^{47}$

The protagonist absorbed that sight with a kind of irritation. That persistence of customs, social relations, and objects made him realise that in the world from which he came such material space-time reduplications were not possible: "Oh, hell - Tadeusz cursed in his mind. " - No one resettled them here by force! No one threw them out of their apartments! Nothing they had got broken! Nothing has been stolen from them!"48

The biblical analogy returned once again. First, a child's recollection from a religious education class, from which he remembered that Noah's ark landed on Mt. Ararat in Armenia. That was later verified with his experiences as a history and culture researcher, who learnt of apocryphal stories about various other locations at which the biblical ship was supposed to have its numerous stops. For Tadeusz, the Italian professor's house became one such mythical place, erected on a symbolic hill. It seemed as if the ark had reached it, leaving some of the crew "with their belongings, habits, high spirits, porcelain, and Maiolica, indifference to the fate of the world, and aprons and cauls for female servants." ${ }^{\prime 9}$ Those were some kinds of endosporic dormant forms, which returned to life after the war.

So, it was not Noah who became the figure of the protagonist's fate; he was more strongly related to Odysseus. Noah secured his family and belongings and saved them. The parabolic image of Tadeusz's fate was not the biblical deluge but the Cyclops's cave and his escape from it. Odysseus escaped tied to a ram's belly: "The ram exited «heavy in wool and me, which I had considered thoroughly.»" The only things Homer's protagonist saved were his life and his "conscious mind."50 Everything else perished in the depths of war. Yet there are other faces of both Noah and Odysseus. They became the figures for the entire surviving population. Both, having paid homage to their gods, returned to their old paths:

From the ark there emerged a bunch of people who would soon fill the Earth with all kinds of misdeeds. Odysseus, having just narrowly escaped

\footnotetext{
${ }^{47}$ Ibid.

${ }^{48}$ Ibid.

${ }^{49}$ Ibid., 42-43.

${ }^{50}$ Ibid., 44 .
} 
death, already started looking around from whom he could steal a ship, cattle or a heard. Disasters did not improve humanity. ${ }^{51}$

Venice - viewed as "the second homeland of the humanist/scholar," 52 with its architecture and historical sites - became an endless source of reflections on philosophy, ethics, philosophy of history, philology, and musicology. In it, biblical and Greco-Roman traditions are intertwined, yet there are also traces of another, less emphasised tradition, i.e. the "barbarian" one. They provoke the protagonist to use in them almost an academic discourse, e.g. in the fragment:

Unlike in Ovid's works, folk tales more often feature a longing for liberation from a lower form of evolution, the motif of lifting a spell, and a premonition about new shapes. It would be interesting to study in detail the differences in terms of the concept of regressive disaster and evolutionary transformation and their motivations in Ovid's Metamorphoses and in folk tales (crime, weakness, breaking promises, and sinful curiosity).

Probably the only example of a dual evolution - at the same time and in parallel from and to human - is the famous section in Song 25 of Dante's Inferno: a dialectic combination of a reptileman and a manreptile. Organic regression and evolution. A strange genetic and poetic counterpoint. ${ }^{53}$

Yet the Venice which Tadeusz explored had another face. He discovered it partly because of curiosity, partly because of his unexpected love for a Venetian woman, and partly, and how trivial it was, because of a his rather low financial status as a researcher from Eastern Europe. What emerged was a record of the city and locations "not visited by tourists" 54 ; readers learn its secrets, smells, flaws, and shortcomings, which in their ugliness were fascinating, and, through Kubacki's descriptions, actually beautiful. What formed were images vividly captured:

One time, he waited for Zanze in a recess by the stairs which descended to water in increasingly greener steps. The final step was a mixture of water and stairs. A dark green unison of water and marble. Harmony and solace. Nearby, there was a boat painted bright blue. Its overturned spectre drew the observer's attention. The piercing blue of the dingy, shifted a tad down within the colour scale, modulated its reflection to a very soft navy blue..$^{55}$

Kubacki's care for colours and his ability to subtly refer to them was exceptional. His Venice radiated with colour. Everything had some colour and each one had to be named, whether that applied to the colour of basilica mosaics, the tones of Venice's canal water, the hue of snail shells and fish

\footnotetext{
${ }^{51}$ Ibid., 44-45.

${ }^{52}$ Czerwiński, Kubackiego obrachunki klerkowskie, 1032.

${ }^{53}$ Kubacki, Smutna Wenecja, 51.

${ }^{54}$ Ibid., 62.

55 Ibid.
} 
scales, the colours of women's dresses, or the shades of Venice's sky. Kubacki's extremely sensual descriptions were synaesthetic. Sounds, tastes, colours, smells, and textures mixed constantly. Colours and sounds overlapped each other the most often, forming exceptionally vibrant and almost poetic synaesthetic passages.

The Venice of recesses was a space of its inhabitants, where colourful underwear dries on lines, where children play, where at the corner of del Cristo and calle dell'Oca "two elderly women dressed in black and buttoned up deliberate from the windows of opposite houses (...) the morning quarrel of a young married couple on the second floor and the lunch plans of the tenants on the first floor." 56 The space is dominated by the smell of "mud, reed, and willow thicket," 57 and of dampness, mould, and mustiness.

\section{The Venice of "unbridled excess." 58 The Venice of the proletariat}

What is extremely interesting is the contrast between two Venetian realities: the world of visitors (mostly tourists) and that of the locals. Those realities are somewhat parallel. Tadeusz entered both; in his experience they overlapped and complemented each other. The former was both attractive for its noise and diversity and repulsive for those same reasons. In the description of St. Mark's Square, a biblical metaphor proved invaluable once more: "The Piazza somewhat resembles Noah's opened ark, from which all creates, a pair of every species, emerged. But also somewhat the Tower of Babel. All races, languages and attires flew through it." ${ }^{15}$

In that "Piazza's mess," as he called it, the author saw a surprising analogue between the stylistic and cultural homogeneity of the local street architecture with its "ancient steeds, Byzantanism, Mauretanness, and Gothic Christianity. All those places were filled with a similar multitude of forms." ${ }^{60}$ Tadeusz, usually tolerant for the "movement and noise" ${ }^{\prime 61}$ caused by the visitors, sometimes expressed his vexation, irritation, or even a sense of superiority:

Islands of tables and chairs, weaved with colour nylon. Around them, motley blobs of international folk gathered. Those who emerged alive when the deluge water receded pounced crazily at the "carcass" left by fate. They travel visiting museums and churches. They learn about Renaissance painters and architects. They indulge in music. They are ready to think God-knows-what about their soulfulness. And in reality, they are simply gnawing a bone they dug up! Each one diligently looking for their own bone! Pro-deluge creatures! Crowmen ${ }^{12}$

\footnotetext{
${ }^{56}$ Ibid.

${ }^{57}$ Ibid., 27.

${ }^{58}$ Ibid., 201.

${ }^{59}$ Ibid., 57.

${ }^{60}$ Ibid.

${ }^{61}$ Ibid., 58.

62 Ibid.
} 
The image of the raven appeared once more, and in a rather ambiguous manner. What Kubacki wrote about it might suggest that its source was not only the biblical tradition. That offers only such a passage: "At the end of forty days Noah opened the window of the ark that he had made and sent forth a raven. It went to and from until the waters were dried up from the earth." ${ }^{63}$ However, the story of a deluge also existed in other cultures (Sumerian and Akkadian), to which, in fact, the Old Testament story was related (a raven appeared only in the Epic of Gilgamesh). ${ }^{64}$ The motif of a raven which instead of returning to the Ark focussed on devouring human remains or some carcass it found, comes from the Talmud/Midrash writings. ${ }^{65}$ However, unlike in the version in which the raven's behaviour is summarised with the conclusion, "To send an impure being ${ }^{66}$ is like sending a fool, and to send a poor being is like sending a trusty messenger," ${ }^{\prime 67}$ Tadeusz's evaluation of the scavenger is contrary: "From the perspective of one of those who were doomed to drown and yet survived, the raven seemed far more honest that the biblical patriarch. It simply, without any redundant fuss of some spirituality, it dined à la fourchette on the buffet left to it by the kind arm of Providence of various meats." ${ }^{\prime 68}$

That exegesis of the biblical symbol did the bird justice, which was only following its instinct fulfilling, in all honesty, the will of its Creator, who gave it that instinct. Is that not ironic? And does such a reading apply to scavenger tourists? As at other locations throughout Kubacki's novel, in this case not only threads but also specific words and phrases are repeated, such as the word "soulfulness." By dint of such links, the threads engage in a kind of a dialogue.

The worlds of the Venetians and visitors rarely interact. If they do, that happens within a service-provider and service-recipient paradigm, where the latter is always in an advantageous position. It is a world of porters, servants, boys, hotel service-people, gondoliers, and waiters juxtaposed against "aged ladies," "old crones" with multitudes of packages, "cases, travel boxes, and bulging bags," ${ }^{\prime 69}$ and young women accompanied by fat gentlemen with cigars in their mouths. ${ }^{70}$ Kubacki painted the world of tourists with somewhat caricature colours.

The descriptions of Venetians were much subtler. Every urban social structure includes people of various material, cultural, and professional statuses. Kubacki was interested predominantly in the Venetian proletariat. The following sentence concisely summarised their life: "The tale of merry

${ }^{63}$ Genesis 8: 6-7; English version: Bibles, Crossway. The Holy Bible, English Standard Version (with Cross-References). Good News Publishers. Kindle Edition.

${ }^{64}$ Antoni Marczewski, "Interpretacje motywu kruka z opowiadania o potopie," Verbum Vitae, issue 32, (2017): 57-58.

${ }^{65}$ Andrzej Szyjewski, Symbolika kruka. Między mitem a rzeczywistościa (Krakow: Nomos, 1991), $72-74$.

${ }^{66}$ The raven belonged to a group of birds which were considered impure in the Hebrew tradition. Vide Levictus 11: 13-19.

${ }^{67}$ Marczewski, Interpretacje motywu kruka..., 60.

${ }^{68}$ Kubacki, Smutna Wenecja, 23.

${ }^{69}$ Ibid., 80.

${ }^{70}$ Ibid., 81-82. 
islands has drowned in soap foam, basement vapours, and stinky recesses." ${ }^{\prime 11}$ The exaltations of an aesthete triggered by encounters with highly tasteful Venetian art clash with the sense caused by Venetian mediocrity, which is shoddy and superficially religious. Just as in the case of the apartment in which Tadeusz, receiving a minor university allowance, was forced to rent a room:

Tadeusz's little room was the hosts' bedroom. Most of it was occupied by a wide iron bed. On its end, there was a greyish lake painted. Two white bulging swans were swimming on its surface towards one another. More or less at the place where the couple's heads were supposed to rest, the swans were extending their necks and touched with the red beaks. It seemed like the caresses of two carrots. (...) The walls with filled with paintings of Sacred Hearts, Immaculate Conceptions, and a whole gallery of popes.

So, there are places and things where Venetian everydayness did not differ much from pontifical Venice. Those were all the forms of animate and inanimate nature, which the protagonist experienced at municipal fish, vegetable, and fruit markets. He saw works of art in all that which he saw there, and he described them in the applicable manner. To use Zanze's mistrustful question for Tadeusz: "Fish market as an artistic adventure?" Yes, that was a regular visit to the market. The shapes, colours and textures were inspiring:

Nearby, on a broad board, an extraordinary fish was drawing its final breaths. Half of its body was a violet iris; the other was a yellow water lily or a water chrysanthemum. Its delicate fins were spread like a flower's petals. In its underwater dance, it would mix both its colours into the greenness flow of the waves. It would become part of the element. It was dying in reality to live pantheistically. The net extracted the fish from the green wave. ${ }^{72}$

Kubacki's Venice was dominated by one more sensory experience: taste. In following Tadeusz, one could recreate a map of Venetian restaurants, trattorias, bars, and inns. One could discover quite ordinary regional tastes, all the "spaghetti or cannelloni (...), green lasagne or tagliatelle with spinach juice (...), fettuccine done the Roman style."73 A meal could become an almost mystical experience, a contemplation, like when Tadeusz was served a platter of steaming cozzas: "Holding the snail down with a spoon, Tadeusz slid his fork into the break between the shells and turned it gently. The tiny hinges cracked. The opened cozza looked like a beautifully polished folding steel mirror (...) The tightly closed shells included some additional salty almond-smelling water, which Tadeusz drank lifting the shell in his fingers to his lips." ${ }^{\prime 4}$

\footnotetext{
${ }^{71}$ Ibid., 147.

${ }^{72}$ Ibid., 53.

${ }^{73}$ Ibid., $160-161$.

${ }^{74}$ Ibid., 25.
} 
The novel is filled with references to cuisine. Almost every day and almost every place was marked by tastes. The author did not refrain from mentioning them even if the protagonist was only having a pizza Margherita or when he ate canned sardines with oranges. It did not matter whether it was a meal or a feast - it always seemed to him worth describing. Those descriptions had various intensities; sometimes they were more intellectual, and more often than not, sensory. The novel's language is a constant balancing between "a vitalist and intellectualised atmosphere."75

Another exceptional example of a clash between visitors to Venice and Venetian locals can be found in the description of culinary experiences. The first such experience occurred at the Four Fountains trattoria in St. Fusca Square, while the second happened in a nameless fish market between shacks, tents, booths, and butcher's stalls.

The former began with the maitre d'hotel who gave Tadeusz a list of dishes bound in raspberry Saffian. The chef and two waiters formed a cortège. The serving of dishes became a complex almost religious ritual, which anxious guests watched in devout tension. The maitre d'hotel introduced the chef:

surrounded by (...) a pair of boy acolytes. One of them removed the cover from a basin. Everyone waited until the steam lifts. Then the other altar boy offered the grand sacrificer a flat spatula and a strangely shaped ladle. At that moment, the maitre d'hotel considerately moved aside. The altar boys donned devout facial expressions. The archpriest extracted from the enamelled basin one branzino after another. The attentive lower deacons of the culinary effectuation offered their plates holding them through white serviettes as if chalices of some peculiar service. ${ }^{76}$

Further on there is an extensive detailed description of the professional filleting of fish which ended with a signal given by the chef, at which point "the entire staff withdrew in a liturgical procession." ${ }^{17}$ The language of a religious service used by the narrator turned the rather common and sensory activity of consuming a meal into an experience bordering on mystical.

At the other extreme, there is a description of a "folk ceremony of boiling and eating a squid."78 Thus, there is a point of intersection, the ceremony: high in the former case, low in the latter. It was recounted in a fairly abbreviated form:

A bunch of ragamuffins silently surrounded the table, a stump with butcher's tools, and a black pot, which was lazily licked by flames which seemed pale in daylight.

A thin weather-beaten man in an oilcloth apron raised the huge cover of the pot and stuck a huge fork into the bursting steam, which seemed like Neptune's trident borrowed from some ancient repository. Over the

\footnotetext{
${ }^{75}$ Rohoziński, Wacław Kubacki, 5 .

${ }^{76}$ Kubacki, Smutna Wenecja, 32.

${ }^{77}$ Ibid., 33.

${ }^{78}$ Ibid., 144.
} 
rising block of steam there appeared in all its glory the Sepiida stuck on the trident. The man in the oilcloth apron gave some triumphant cry and shook the trident. The cuttlefish's arms danced in the air. A new cry emerged from the throat of the thin weather-beaten man. The people who surrounded the pot parted quickly. The Sepiida slid from the fork and smacked heavily on the table splashing murky juice all around. The crowd of ragamuffins merrily surrounded the steaming body again. The thin man in the oilcloth apron poured some salt from a paper bag and quickly cut the cuttlefish's arms with a broad knife dividing the octopus into numerous slices, some thin and others thick. ${ }^{79}$

Both ceremonies drew their descriptions from two different cultural sources - an elitist liturgy/feast vs. an egalitarian folk public custom. The former described using the language of a religious pompous ritual; the latter using that of a lively somewhat barbarian rite. The studied restrained ritual stood in contrast to the vivid folk event. The descriptions of both include the novel's trademark variational repetitions. In these two cases, those applied to entire scenes and their components. Both had their masters of ceremony, a "sacrifice," and the audience.

The Venice depicted by Kubacki was a dual city. In that perception the author matched the manner of its depiction established in literary traditions. That clash seems to be what carries its power to fascinate. It is usually the contrast between the high and the low fulfilled in various spaces. Thus, the novel depicts the Venice of architectural masterpieces and the dimness of tenement houses with their damp vestibules and gloomy alcoves. There are mosaics, sculptures, paintings by "Titian Tintoretto, Veroneso, Giorgion, the Bellinis, the Canalettis, Tiepol," 80 and the swans adorning the bed of the Venetian couple and the holy images hanging all over the walls of their apartment. There is the Venice of showroom shops from the main street, and that of fish markets, fruit and vegetable stands, and butcher's stalls; the Venice of lavish restaurants, and that of small trattorias; the Venice of foreign women in colourful trendy dresses, and the city of old black-dressed women spending their time sitting in front of houses. The Venice of organ music, arias, and concerts resonating from churches and squares, and the Venice of the overwhelming gibberish of markets, "the clatter of hammers and the rattle of carts," 81 and "the reverberating clacking of wooden shoes on stone slabs." ${ }^{12}$ Both cities were equally worth writing about and equally "Venetian."

In Kubacki's novel, Venice seems a character more important than Tadeusz or Zanze. The writer considered the city from different sides and from each it seemed to him intriguing and inspiring. In the novel, the language of intellectual discourse clashes with that of lively sensory descriptions. Yet it is not the case that the intellectual language is assigned to the "high" Venice while the language focussed on sensory experiences is assigned to the "low"

\footnotetext{
${ }^{79}$ Ibid., 144-145.

${ }^{80}$ Ibid., 20.

${ }^{81}$ Ibid., 130.

${ }^{82}$ Ibid., 144.
} 
Venice $^{83}$ They sometimes overlap. For example, when seemingly common items become aesthetic as well as intellectual inspirations. That is the case in the description of the fish viewed at the market, in whose colours and arrangements of scales Tadeusz saw similarity to the structure of an artistic mosaic:

That loose skittish arrangement of light spots. And its image is always divided into tiny independent lines, spots, and marks. Nothing finished. Classic divisionism! The fish is something in between a mosaic and a work by an impressionist. And one more thing. Both the fish and a mosaic are a complete colour scale. Their modulation is naturally strong and bold by necessity. One could even talk about colourful diatone. Finally, in both cases, everything depends on the light: the colours of the fish and the colour arrangements of mosaics. ${ }^{84}$

I have already indicated that musical threads recur throughout the novel. The author described his musical experiences or used musical metaphors. Thus, a soprano aria from Monteverdi's Vespro della Beata Vergine admired at the della Salute church became a pretext for an almost poetic description of longing for the lover ${ }^{85}$, and gondolas rocked in a syncopated rhythm. ${ }^{86}$ In the structure and the composition of the novel, one might find stylistic devices resembling the movement of waves. It often includes particular (intentional and meaningful) repetitions of passages within relatively short fragments. Certain scenes and images, though much more spread apart, also recur, yet they were constructed in such a way that they immediately signal those which occurred before. They engage in an obvious dialogue with one another. Those doubles - leitmotifs, if you will - resemble waves repeatedly crashing on the shore.

The common accumulation of words is another trademark stylistic feature of the novel. When discussing it, Maciagg argued that through it the author expressed "the value of words, the value of the act of naming." ${ }^{17}$ According to him, in those thesaurus-like series the narrator was making his statement, whom he defined as a linguistic "sensorist and creationist." 88 Those dictionary sequences include several dozen items each. Kubacki thus described jewellers' displays in Venetian streets:

Tadeusz (...) being pushed, jostled, and shaken when faced with the shiny displays wandered polarised by the values, over-saturated, honoured, and overwhelmingly multiplied by crystals, silvers, platters, enamels, precious stones, jewels, mothers-of-pearl, Venetian mirrors, Persian embellishments and Mauritanian incrustations, pressed and gold-leafed

\footnotetext{
${ }^{83}$ In that focus on sensory experiences as well as in the ability to "specifically mirror the whole specificity and the particular atmosphere of Italian reality, nature, and life," Rohoziński saw inspiration drawn from Iwaszkiewicz. See also: Rohoziński, Wacław Kubacki, 5.

${ }^{84}$ Kubacki, Smutna Wenecja, 109.

${ }^{85}$ Ibid., 55.

${ }^{86}$ Ibid., 9.

${ }^{87}$ Maciąg, Eseistyka i powieść, 112.

${ }^{88}$ Ibid.
} 
leather, fantastically cut perfume bottles, beads, ear clips, rings, brooches, pendants, chainlets, bracelets, lace, silk, the fluff of flowery carpets, and the shine of rare Siberian and Canadian furs. ${ }^{89}$

The many accumulations reflect the sensory intensity with which the protagonist experienced Venetian reality with its peculiar excess of all goods offered by the city to a receptive visitor open to such experiences. The more receptive because of the place where he had come from: a country of greyness and trumpery. Usually the protagonist was charmed by the excess, yet there were times when (like in the quoted fragment) he was overwhelmed. The highest accumulation can be found when Tadeusz viewed a painting in the basilica of a biblical scene of multiplying fish and bread. Christ seemed to him as an "inspired creationist" tion could not have, according to the protagonist, produced simply more bread but it also had to bring a multitude of all other baked goods:

Prażucha, barley flatbread, Jewish matzah, Armenian lavash, Georgian khachapuri, Turkish tsoureki, sailor's hardtacks, Italian pizza (...) butter scones and marmalade-stuffed scones, solanka rolls, kaiser rolls, pretzels, bagels, boobliks, Parisian croissants and brioches, sticks, pastries, dumplings, fritters, coulibiacs (...) waffles, wafer biscuits, macaroons, marzipan, bałamutka rolls, nougats, and makagigi. And many, many more other ideas for baked goods, with an excess bake of twelve baskets of fragments and crumbs. ${ }^{91}$

That is just a small fragment of an over-one-page-long enumeration of around 140 kinds of baked goods. That abundance of enumerations, listings, and catalogues resembles the phenomenon present in art since the beginning, which Umberto Eco discussed in The Infinity of Lists: "The fear of being unable to say everything seizes us not only when we are faced with an infinity of names but also with an infinity of things. The history of literature is full of obsessive collections of objects." ${ }^{\prime 92}$

Kubacki's Smutna Wenecja is such an "obsessive collection of things," which are the source of endless inspiration and stimulation, and delights, both intellectual and sensory. Symptomatic words are included at the end of the novel when a friend accuses Tadeusz of "grazing" too long in Venice. That is the perception of Venice described by Kubacki. It is a place for "grazing" - for the intellect, the spirit, and the senses.

There is also the issue of the title. It seems banal and unpretentious without being obvious. That was proven by its German version: Abschied von Venedig (Farewell to Venice), which must have been approved by the

\footnotetext{
${ }^{89}$ Kubacki, Smutna Wenecja, 56.

${ }^{90}$ Ibid., 91.

${ }^{91}$ Ibid., 91-92.

${ }^{92}$ Umberto Eco, Szaleństwo katalogowania (Poznań: Rebis 2009), 67. [English version: Eco Umberto, The Infinity of Lists (Random House Incorporated, 2009)]
} 
writer. ${ }^{93}$ Why did he describe Venice as being sad? Mind you, it offered the protagonist many inspiring aesthetic, intellectual, and sensory experiences. Sadness did accompany the parting of the lovers. The protagonist's Venetian love affair ended abruptly. It was severed unceremoniously, against the intentions of the couple, by politics and various schemes. For Tadeusz, it offered yet another trigger of cultural associations and reflections (bidding him farewell Zanze, standing alone in the rain on a pier, seemed to him like a scene from a Venetian mosaic). Yet the essence of the novel cannot be simply reduced to the love story. Therefore, Venice seems sad mainly as a metaphor of Western civilisation, bringing the writer to bitter reflections. In this case, the "sadness" seems approximate to the poetic term of "smętek" [unhappiness]. Venice could also be defined as melancholic, nostalgic, and pensive - that was the image of the "city on water" drawn by Kubacki.

\section{REFERENCES}

Czerwiński, Marcin. "Kubackiego obrachunki klerkowskie." Nowe Książki, issue 15, (1968): 1032-1033.

Dybciak, Krzysztof. “Inwazja eseju.” Pamiętnik Literacki, issue 4, (1977): 113-150.

Eco, Umberto. Szaleństwo katalogowania. Poznań: Rebis, 2009.

Kubacki, Wacław. Abschied von Venedig. Trans. Caesar Rymarowicz. Berlin: Rütten \& Loening, 1971.

Kubacki, Wacław. Adam Mickiewicz: człowiek i dzieło. Krakow: PWN, 1966.

Kubacki, Wacław. "Amiel (Fantazja biblijna w 4 aktach)." Dialog, issue 4, (1957): 5-31.

Kubacki, Wacław. Arcydramat Mickiewicza: studia nad III częścia „Dziadów." Krakow: Wydawnictwo M. Kot, 1951.

Kubacki, Wacław. Człowiek i świat. Warsaw: Krajowa Agencja Wydawnicza, 1988.

Kubacki, Wacław. Dziennik (1944-1958). Warsaw: Czytelnik, 1971.

Kubacki, Wacław. Dziennik 1959-1965. Warsaw: Państwowy Instytut Wydawniczy, 1974.

Kubacki, Wacław. Dziennik. (1966-1968). Warsaw: Państwowy Instytut Wydawniczy, 1990.

Kubacki, Wacław. "Historia biblijna." Twórczość, issue 12, (1949): 84-99.

Kubacki, Wacław. Jakobińskie gniazdo. Sztuka z insurekcji warszawskiej w 6 obrazach. Warsaw: Czytelnik, 1955.

Kubacki, Wacław. Kartki na wietrze. Bydgoszcz: Arkona, 1950.

Kubacki, Wacław. Koncert na orkiestrę. Warsaw: Czytelnik, 1970.

Kubacki, Wacław. Krytyk i twórca. Łódź: Wydawnictwo Władysława Bąka, 1948.

Kubacki, Wacław. Krzyk jarzębiny: opowieść dramatyczna w trzech aktach. Warsaw: Państwowy Instytut Wydawniczy, 1949.

${ }^{93}$ Wacław Kubacki, Abschied von Venedig, trans. Caesar Rymarowicz (Berlin: Rütten \& Loening, 1971). Other translations of the novel reflect its original title (e.g. Russian Grustnaja Venecija, Romanian Tristia Venetie, or Lithuanian Liudnoji Venecija). 
Kubacki, Wacław. Lata terminowania. Szkice literackie 1932-1962. Krakow: Wydawnictwo Literackie, 1963.

Kubacki, Wacław. Malwy na Kaukazie. Warsaw: Czytelnik, 1969.

Kubacki, Wacław. „Monachomachia” przed sądem potomności. Warsaw: Książka i Wiedza, 1951.

Kubacki, Wacław. Na scenie. Warsaw: Wydawnictwa Artystyczne i Filmowe, 1962.

Kubacki, Wacław. Palmira i Babilon. Wrocław: Wydawnictwo Zakładu Narodowego im. Ossolińskich, 1951.

Kubacki, Wacław. "Paw i dziewczyna. Balet w 1. akcie.” Zeszyty Wrocławskie, issue 3-4, (1949): 50-51.

Kubacki, Wacław. Pierwiosnki polskiego romantyzmu. Krakow: Wydawnictwo M. Kot, 1949.

Kubacki, Wacław. Poezja i proza. Studia historycznoliterackie 1934-1964. Krakow: Wydawnictwo Literackie, 1966.

Kubacki, Wacław. Rzymska wiosna. Sztuka w 3 aktach. Warsaw: Czytelnik, 1955.

Kubacki, Wacław. Sen nocy letniej. Poznań: Wydawnictwo Poznańskie, 1974.

Kubacki, Wacław. Smutna Wenecja. Warsaw: Czytelnik, 1967.

Kubacki, Wacław. Smutna Wenecja. 2nd edition. Warsaw: Czytelnik, 1968.

Kubacki, Wacław. Smutna Wenecja. 3rd edition, Warsaw: Czytelnik, 1971.

Kubacki, Wacław. Temat z wariacjami. Warsaw: Państwowy Instytut Wydawniczy, 1982.

Kubacki, Wacław. Tragedia Achillesa oraz inne próby dramatyczne. Poznań: Wydawnictwo Poznańskie, 1972.

Kubacki, Wacław. "Tragedia Achillesa. (W swobodnej formie antycznej)." Dialog, issue 5, (1970): 7-29.

Kubacki, Wacław. Twórczość Feliksa Bernatowicza. Wrocław: Wydawnictwo Zakładu Narodowego im. Ossolińskich, 1964.

Kubacki, Wacław. Tyrteizm Adama Mickiewicza. Warsaw: [s.n.], 1949.

Kubacki, Wacław. Z Mickiewiczem na Krymie. Warsaw: Państwowy Instytut Wydawniczy, 1977.

Kubacki, Wacław. Żeglarz i pielgrzym. Warsaw: Czytelnik, 1954.

Maciąg, Włodzimierz. "Eseistyka i powieść." Twórczość, issue 11, (1967): 110-113.

Marczewski, Antoni. "Interpretacje motywu kruka z opowiadania o potopie." Verbum Vitae, issue 32, (2017): 55-70.

Pellico, Silvio. Moje więzienia. Pamiętniki z przypisami Piotra Maroncellego, trans. F. Tustanowski, vol. 1-2. Vilnius: Nakład wydawcy, Drukarnia B. Neumana, 1837.

Rohoziński, Janusz. "Wacław Kubacki." Tygodnik Kulturalny, issue 30, (1968): 4-5.

Różewicz, Tadeusz. Niepokój. Wiersze z lat 1945-1946. Wrocław: Wydawnictwo Zakładu Narodowego im. Ossolińskich, 1980.

Szałagan, Alicja. “Kubacki Wacław.” In Współcześni polscy pisarze i badacze literatury. Stownik bibliograficzny, vol. 4, edited by a team led by J. Czachowska and A. Szałagan. Warsaw: Wydawnictwa Szkolne i Pedagogiczne, (1996): 425-429. 
Szyjewski, Andrzej. Symbolika kruka. Między mitem a rzeczywistością. Krakow: Nomos, 1991.

Zieliński, Stanisław. "Miłość z dobrym apetytem." In:, Wycieczki balonem. No 4. Warsaw: Państwowy Instytut Wydawniczy, 1971.

Magdalena Kuran - University of Lodz, Department of Language Teaching and Polish Literature. Academic focus: Old Polish preachers, religious motifs in Old Polish literature, rhetoric. Major publications: Retoryka jako narzędzie perswazji w postyllografii polskiej XVI wieku (na przykładzie "Postylli katolicznej" Jakuba Wujka), Łódź 2007.

E-mail: magdalena.kuran@uni.lodz.pl 